\title{
Partisipasi Guru Penjas Dalam Membina Prestasi Usia Dini Di Tim Gala Siswa SMP 6 Banda Aceh Tahun 2020
}

\author{
Fanny Sayudi ${ }^{1}$, AB Muammar ${ }^{2}$ \\ ${ }^{1}$ Dosen Fakultas Keguruan dan Ilmu Pendidikan Universitas Serambi Mekkah \\ ${ }^{2}$ Alumni Fakultas Keguruan dan Ilmu Pendidikan Universitas Serambi Mekkah \\ fani.aceh@gmail.com
}

\begin{abstract}
Abstrak
Penelitian yang berjudul. "Partisipasi Guru Penjas Dalam Membina Prestasi Usia Dini Di Tim Gala Siswa Smp 6 Banda Aceh Tahun 2020". Adapun permasalahan Prestasi usia dini Tim GALA SISWA SMP 6 Banda Aceh belumlah memperoleh hasil yang baik, ini terlihat dalam beberapa turnamen yang diikuti selalu kalah di awal - awal turnamen, hal ini dikarenakan oleh beberpa faktor antara lain kurang berpartisipasinya guru penjas dalam membina Tim GALA SISWA SMP 6 Banda Aceh serta kurangnya latihan dalam menghadapi suatu turnamen. Penelitian ini dapat digolongkan dalam penelitian deskriptif. Dalam penelitian ini populasi dalam penelitian ini adalah seluruh Guru pendidikan jasmani pada SMP Negeri 6 Kota Banda Aceh yang berjumlah 2 orang. Teknik pengambilan sampel penelitian ini adalah dengan total sampling, maka jumlah sampel yang digunakan dalam penelitian ini sebanyak 2 orang. Tehnik analisis data yang digunakan adalah sebagai berikut : Data yang diperoleh dari hasil angket yang dilakukan terhadap 2 orang sampel diolah dan dianalisis dengan metode distribusi frekuensi. Hasil penelitian tersebut menunjukan bahwa Guru penjasorkes pada SMP 6 kota Banda Aceh pada umumnya telah berupaya partisipasi dalam membina prestasi usia dini di Tim Gala Siswa. Guru penjasorkes pada SMP 6 kota Banda Aceh terkendala dengan lingkungan sekolah yang kurang mendukung dalam membina prestasi usia dini di Tim Gala Siswa
\end{abstract}

\section{Kata kunci : Prestasi Usia Dini Di Tim Gala Siswa}

\section{PENDAHULUAN}

Pendidikan jasmani merupakan bagian dari pendidikan (secara umum) yang berlangsung melalui aktifitas yang melibatkan mekanisme gerak tubuh manusia dan menghasilkan pola-pola prilaku individu yang bersangkutan. Pendidikan jasmani menurut Soepartono (2000 : 1) merupakan pendidikan yang menggunakan aktifitas sebagai media utama untuk mencapai tujuan.

Anak usia dini adalah individu yang sedang mengalami proses pertumbuhan dan perkembangan yang sangat pesat, bahkan dikatakan sebagai lompatan perkembangan. Anak usia dini memiliki rentang usia yang sangat berharga dibanding usia-usia selanjutnya karena perkembangan kecerdasannya sangat luar biasa. Usia tersebut merupakan fase kehidupan yang unik, dan berada pada masa proses perubahan berupa pertumbuhan, perkembangan, pematangan dan penyempurnaan, baik pada aspek jasmani maupun rohaninya yang berlangsung seumur hidup,bertahap, dan berkesinambungan

Hamalik (dalam Arsyad, Azhar, 1997: 3) mengemukakan bahwa: “ Anak usia dini merupakan individu yang berbeda, unik, dan memiliki karakteristik tersendiri sesuai dengan tahapan usianya. Pada masa ini stimulasi seluruh aspek perkembangannya memiliki peran penting untuk tugas perkembangan selanjutnya. Sel- 
sel tubuh anak usia dini tumbuh dan berkembang sangat pesat, pertumbuhan otak pun sedang mengalami perkembangan yang sangat luar biasa, demikian halnya dengan pertumbuhan dan perkembangan fisiknya. Tahap awal perkembangan janin sangat penting dalam pengembangan sel-sel otak, bahkan ada yang berpendapat bahwa saat lahir jumlah sel otak tidak bertambah lagi. Selanjutnya setelah lahir terjadi proses eliminasi dari sel-sel saraf dan pembentukan hubungan antarsel. Dalam hal ini terdapat dua hal yang sangat penting dan diperhatikan dalam pembentukan kecerdasan; yaitu makanan yang bergizi dan seimbang serta stimulasi yang positif dan kondusif, sebab dengan keterbatasan media yang mampu disediakan sekolah tersebut justru menjadi tantangan yang harus diatasi oleh pihak sekolah bersama dengan guru Pendidikan Jasmani guna mencari solusi terbaik untuk permasalahan ini.

Prestasi usia dini Tim GALA SISWA SMP 6 Banda Aceh belumlah memperoleh hasil yang baik, ini terlihat dalam beberapa turnamen yang diikuti selalu kalah di awal - awal turnamen, hal ini dikarenakan oleh beberpa faktor antara lain kurang berpartisipasinya guru penjas dalam membina Tim GALA SISWA SMP 6 Banda Aceh serta kurangnya latihan dalam menghadapi suatu turnamen.

Dalam hal ini guru dituntut berpartisipasi dalam membina prestasi usia dini di Tim Gala Siswa SMP 6 Banda Aceh. Untuk membuktikan permasalahan di atas penulis tertarik untuk melakukan penelitian dengan menetapakan judul: "Partisipasi Guru Penjas Dalam Membina Prestasi Usia Dini di Tim GALA SISWA SMP 6 Kota Banda Aceh Tahun 2020".

\section{Tujuan Penelitian}

Berdasarkan dari latar belakang diatas, maka yang menjadi tujuan penelitian ini adalah:

1. Untuk mengetahui partisipasi Guru Penjasorkes dalam membina usia dini pada SMP Negeri di Kota Banda Aceh.

2. Untuk mengetahui hambatan Guru dalam mengembangkan pembinaan usia dini pada SMP Negeri di Kota Banda Aceh.

\section{KAJIAN TEORITIS Pengertian Guru}

Menurut kamus besar Bahasa Indonesia, Guru adalah orang yang pekerjaanya (mata pencahariannya, profesinya) mengajar (Moeliono, 1988:288). Menurut undangundang pendidikan Nasional, Pendidik merupakan tenaga profesional yang bertugas merencanakan proses pembelajaran, menilai hasil pembelajaran, melakukan bimbingan dan pelatihan serta melakukan penelitian dan pengabdian kepada masyarakat, terutama bagi pendidik perguruan tinggi (Nurdin, Syafruddin, 2005 : 7).

Guru adalah pendidik professional, karenanya secara implisit ia telah merelakan dirinya menerima dan memikul sebagian tanggung jawab pendidikan yang terpikul pada pundak orang tua (pendidik lain). Hal ini sejalan dengan pendapat tim metodik bahwa: "Guru dan para pengajar serta pendidik pada umumnya adalah merupakan perintis pembangunan disegala bidang kehidupan masyarakat". Tetapi juga merupakan pahlawan yang tidak dikenal dan tidak mau dikenal (Tim Didaktik metodik, 1989:15).

Mc Leod (dalam Katmiati, 2007:11), berasumsi Guru adalah seseorang yang pekerjaanya mengajar orang lain. Kata mengajar dapat kita tapsirkan misalnya :

1. Menularkan pengetahuan dan kebudayaan kepada orang lain (bersifat kognitif)

2. Melatih ketrampilan jasmani kepada orang lain (psikomotorik)

3. Menanamkan nilai dan keyakinan kepada orang lain (afektip) 
Jadi pengertian guru adalah tenaga pendidik yang pekerjaanya utamanya mengajar (UUSPN). Tahun 1989 Bab VII pasal 27 ayat 3). Guru secara sederhana dapat diartikan sebagai orang yang memberikan ilmu pengetahuan kepada anak didik (Anwar Q \& Sagala S, 2004:120). Karena tugasnya itulah, Guru dapat menambah kewibawaannya dan keberadaan Guru sangat diperlukan masyarakat, mereka tidak meragukan lagi akan urgensi Guru bagi anak didik.

\section{Pendidikan Jasmani Olahraga Dan Kesehatan}

Penjasorkes merupakan salah satu mata pelajaran yang wajib diselenggarakan disekolah, yaitu sebagai mata pelajaran yang pokok yang harus diikuti oleh seluruh siswa. Mata pelajaran ini mempunyai kekhasan dibandingkan dengan mata pelajaran lainnya, yaitu menggunakan aktivitas fisik sebagai sarana/media dalam mendidik siswa (Amir, Nyak. 2005:5). Penjasorkes dilaksanakan dalam rangka mencapai tujuan pendidikan nasional yang mencakup aspek fisik, intelektual, emosional, sosial dan moral. Hal itu sudah tentu tidak akan tercapai dengan sendirinya, tetapi harus melalui proses pengajaran dan pembelajaran yang dikelola dengan sebaik-baiknya.

Undang-undang No.4 tahun 1950 kemudian menjadi Undang-undang No.12 tahun 1954 memberikan landasan kuat terhadap pendidikan jasmani di sekolah. Dalam Bab IV pasal 9 tercantum "pendidikan jasmani yang menuju kepada keselarasan antara tumbuhnya badan dengan perkembangan jiwa untuk membuat bangsa yang sehat, kuat lahir batin dan diberikan pada semua jenis pendidikan".

\section{Guru Pendidikan Jasmani Olahraga Dan Kesehatan}

Suryobroto (2001:71) mengatkan bahwa Guru penjasorkes yang baik dalam proses mengajar penjasorkes harus:

a. Menyiapkan diri dalam hal fisik dan mental

b. Menyiapkan materi pelajaran sesuai dengan kurikulum

c. Menyiapkan alat, pekakas dan fasilitas agar terhindar dari bahaya dan kecelakaan

d. Mengatur formasi siswa sesuai dengan tujuan, materi, sarana, prasarana, metode dan jumlah siswa

e. Mengoreksi siswa secara individual dan klasikal

f. Mengevaluasi secara formatf dan sumatif

Agar mampu menjadi frofil Guru penjasorkes maka dituntut memenuhi persyaratan sebagai berikut: 1) sehat jasmani dan rohani dan berfrofil olahragawan, 2) berpenampilan menarik, 3) tidak gagap, 4) tidak buta warna, 5) intelegen, 6) energik.

\section{Pembinaan Prestasi Anak Usia Dini}

Dalam olahraga usia dini, target yang harus dicapai anak adalah menerapkan sebaik mungkin keterampilan dan kemampuan yang sudah dilatih ke dalam pertandingan. Adalah besarnya usaha dan peningkatan pribadi yang seharusnya dihargai dan menjadi target bagi setiap anak, bukannya semata-mata mencapai kemenangan dalam pertandingan. Tujuan melibatkan anak dalam aktivitas olahraga adalah sebagai pengenalan pengalaman berolahraga, meningkatkan ketrampilan fisik, membangun kepercayaan diri.

Dalam masa ini, yang diperlukan anak adalah kegembiraan dalam melakukan latihan olahraga. Oleh karena itu pelatihnya tidak perlu menekankan pada penguasaan teknik atau peraturan pertandingan. Pujian atau hadiah diberikan kepada usaha yang dilakukan anak, bukan terhadap hasil akhir. Disini perlu ditanamkan perasaan 
"mencapai sukses" bukan hanya sebagai juara, tetapi juga sebagai partisipan. Oleh karena itu, penting sekali di masa awal ini setiap partisipan dalam suatu kejuaraan bisa mendapatkan penghargaan. Persiapan mental dalam menghadapi pertandingan juga merupakan hal yang perlu diperhatikan. Utamanya anak perlu dibiasakan berfikir positif, diberi keyakinan bahwa dalam pertandingan nanti dirinya mampu menampilkan keterampilan yang telah dilatihnya.

\section{Penggolongan Usia Pada Anak Usia Dini}

Anak usia dini merupakan individu yang berbeda, unik, dan memiliki karakteristik tersendiri sesuai dengan tahapan usianya. Pada masa ini stimulasi seluruh aspek perkembangannya memiliki peran penting untuk tugas perkembangan selanjutnya. Sel-sel tubuh anak usia dini tumbuh dan berkembang sangat pesat, pertumbuhan otak pun sedang mengalami perkembangan yang sangat luar biasa, demikian halnya dengan pertumbuhan dan perkembangan fisiknya. Tahap awal perkembangan janin sangat penting dalam pengembangan sel-sel otak, bahkan ada yang berpendapat bahwa saat lahir jumlah sel otak tidak bertambah lagi. Selanjutnya setelah lahir terjadi proses eliminasi dari sel-sel saraf dan pembentukan hubungan antarsel. Dalam hal ini terdapat dua hal yang sangat penting dan diperhatikan dalam pembentukan kecerdasan; yaitu makanan yang bergizi dan seimbang serta stimulasi yang positif dan kondusif.

Usia 13-15 tahun merupakan kelompok usia dini. Remaja adalah masa saat terjadi perubahan-perubahan yang cepat, termasuk perubahan fundamental dalam aspek kognitif, emosi, sosial dan pencapaian termasuk perkembangan fisik (Fagas, 2006).

\section{METODE PENELITIAN \\ Waktu dan Tempat Penelitian}

Banda Aceh.

Jadwal penelitian ini direncanakan akan dilaksanakan pada 31 Agustus 2020 di

\section{Populasi dan Sampel}

Populasi adalah keseluruhan dari subjek penelitian yang akan diteliti hal ini sesuai dengan pendapat Arikunto (1990:115), yaitu "Populasi adalah keseluruhan subjek penelitian". Sesuai dengan judul penelitian, maka yang menjadi populasi dalam penelitian ini adalah seluruh Guru pendidikan jasmani pada SMP Negeri 6 Kota Banda Aceh yang berjumlah 2 orang. Mengingat kecilnya populasi, maka peneliti mengambil semua Guru penjasorkes untuk dijadikan sampel penelitian. Teknik pengambilan sampel dilakukan dengan cara "Total sampling".

\section{Teknik Pengumpulan Data}

Untuk mengumpulkan data penulis menggunakan penelitian lapangan. Untuk mendapatkan data dilapangan terlebih dahulu penulis melakukan observasi, dan menyebarkan angket. Angket ini berisikan beberapa pertanyaan seputar permasalahan tentang partisipasi guru penjas dalam membina prestasi usia dini di team Gala Siswa SMP 6 kota Banda Aceh.

\section{Teknik Analisis Data}

Untuk perhitungan persentase dari semua alternatif jawaban pada setiap pertanyaan sehingga menjadi suatu konsep yang dapat diambil kesimpulan, maka 
penulis mengambil statistik sederhana dengan metode distribusi frekuensi dalam mengalisis data yang diproleh. Hasil data yang diperoleh nantinya akan diolah dengan menggunakan rumus:

$$
P=\frac{f}{N} x 100 \%
$$

Keterangan:

$\mathrm{P} \quad=$ Persentase

$\mathrm{f} \quad=$ Frekuensi

$\mathrm{N} \quad=$ Total sampel

$100 \%=$ Bilangan Tetap

\section{HASIL PENELITIAN DAN PEMBAHASAN \\ Proses Pengumpulan Data}

Data penelitian ini diperoleh melalui angket yang berjumlah 15 pertanyaan dan didukung oleh hasil observasi dilapangan yang diedarkan kepada guru pendidikan jasmani pada SMP 6 Banda Aceh berjumlah 2 guru yang ditetapkan sebagai sampel penelitian. Penelitian ini secara formal penulis laksanakan setelah mendapat surat izin penelitian dalam rangka pengumpulan data skripsi sebagai pengantar dari pembantu dekan bidang akademik Fakultas Keguruan dan Ilmu Pendidikan Universitas Serambi Mekkah.

Pada tanggal 31 Agutus 2020 penulis melakukan koordinasi dengan kepala sekolah Pada SMP 6 Kota Banda Aceh untuk memohon izin melaksanakan penelitian pada Guru Penjasorkes, kemudian dengan bantuan kepala sekolah peneliti mengedarkan angket kepada responden. Selanjutnya pada tanggal 13 Juli 2020 penulis kembali mendatangi sekolah guna mengumpulkan kembali angket yang telah diedarkan kepada responden. Jumlah angket terkumpul sesuai dengan jumlah angket yang telah diedarkan.

\section{Analisis Data}

Untuk mengetahui secara rinci tentang partisipasi guru penjas dalam membina prestasi usia dini di Team Gala Siswa dilakukan penafsiran terhadap jawaban guru yang diperoleh melalui angket. Adapun langkah-langkah yang akan ditempuh adalah Menghitung persentase (\%) setiap alternatif jawaban yang diperoleh dan membuat tabel kemudian menafsirkannya Tabel Ijazah apa yang Bapak/Ibu miliki dalam Mengajar penjasorkes

\begin{tabular}{|c|c|c|}
\hline \multicolumn{1}{|c|}{ Alternative Jawaban } & Frekuensi & Persentase \\
\hline a. Sesuai & 2 & $100 \%$ \\
b. Tidak sesuai & - & - \\
\hline Jumlah & 2 & $100 \%$ \\
\hline
\end{tabular}

Dari tabel diatas menunjukkan bahwa 2 orang guru atau $100 \%$ guru yang mengajar penjasorkes pada SMP 6 Kota Banda Aceh sesuai dengan dengan profesinya. Dengan demikian dapat disimpulkan bahwa, 100\% atau seluruhnya guru yang mengajar pelajaran penjasorkes pada SMP 6 Kota Banda Aceh sesuai dengan profesinya.

Tabel Berapa lama Bapak/Ibu telah mengajar pelajaran penjasorkes di sekolah

\begin{tabular}{|c|c|c|}
\hline Alternative Jawaban & Frekuensi & Persentase \\
\hline a. 1 Tahun & - & - \\
b. 2 Tahun & - & - \\
\hline
\end{tabular}


c. 3 Tahun

d. 4 Tahun lebih Jumlah

\begin{tabular}{|l|l|}
\hline 2 & $100 \%$ \\
\hline 2 & $100 \%$ \\
\hline
\end{tabular}

Dari tabel diatas menunjukkan, 2 orang guru atau 100\% menjawab bahwa, guru yang mengajar penjasorkes pada SMP 6 Kota Banda Aceh menyatakan mengajar penjasorkes lebih dari 4 tahun. Dapat disimpulkan bahwa, 100\% atau keseluruhan guru mengajar penjasorkes pada SMP 6 Kota Banda Aceh menyatakan mengajar penjasorkes lebih dari 4 tahun.

Tabel Pernahkah Bapak/Ibu mengikuti penataran/pelatihan tentang pembinaan usia dini.

\begin{tabular}{|c|c|c|}
\hline Alternative Jawaban & Frekuensi & Persentase \\
\hline a. Pernah & 2 & $100 \%$ \\
\hline b. Tidak pernah & - & - \\
\hline c. Belum pernah diselenggarakan & - & - \\
\hline Jumlah & 2 & $100 \%$ \\
\hline
\end{tabular}

Dari tabel diatas menunujukkan bahwa 2 orang guru atau $100 \%$ pernah ikut pelatihan yang diselenggarakan.

Dari pernyataan diatas dapat disimpulkan bahwa, 100\% atau seluruh guru yang mengajar penjasorkes pada SMP 6 Kota Banda Aceh menyatakan pernah mengikuti penataran/pelatihan tentang media pembelajaran penjasorkes.

Tabel Bagaimana upaya Bapak/Ibu partisipasi pembinaan usia dini

\begin{tabular}{|c|c|c|}
\hline Alternative Jawaban & Frekuensi & Persentase \\
\hline a. Memodifikasi program latihan & 2 & $100 \%$ \\
b. Menggunakan alam sekitarnya & - & - \\
c. Mengajarkan apa adanya & - & - \\
\hline Jumlah & 2 & $100 \%$ \\
\hline
\end{tabular}

Dari tabel diatas menunjukkan bahwa 2 orang guru atau 100\% menyatakan memodifikasi program latihan, Dari pernyataan diatas, jawaban yang benar adalah memodifikasi program latihan, jadi 100\% guru penjasorkes menjawab benar. Dapat disimpulkan bahwa, 100\% atau semua guru yang mengajar penjasorkes pada SMP 6 Kota Banda Aceh berupaya partisipasi pembinaan usia dini.

Tabel Apakah Bapak/Ibu Memahami tentang pembinaan usia dini

\begin{tabular}{|l|c|c|}
\hline Alternative Jawaban & Frekuensi & Persentase \\
\hline a. Paham & 2 & $100 \%$ \\
b. Tidak paham & - & - \\
c. Kurang paham & - & - \\
\hline Jumlah & 2 & $100 \%$ \\
\hline
\end{tabular}

Dari tabel diatas menunjukkan bahwa 2 orang guru atau $100 \%$ menyatakan paham tentang pembinaan usia dini. Dapat disimpulkan bahwa, 100\% atau seluruhnya guru yang mengajar penjasorkes pada SMP 6 Kota Banda Aceh menyatakan paham tentang pembinaan usia dini.

Tabel Apakah Bapak/Ibu memahami tujuan pembinaan usia dini

\begin{tabular}{|l|c|c|}
\hline Alternative Jawaban & Frekuensi & Persentase \\
\hline a. Paham & 2 & $100 \%$ \\
b. Tidak paham & - & - \\
c. Kurang paham & - & - \\
\hline Jumlah & 2 & $100 \%$ \\
\hline
\end{tabular}


Dari tabel diatas menunjukkan bahwa 2 orang guru atau100\% menyatakan memahami tujuan pembinaan usia dini. Dengan demikian dapat disimpulkan bahwa, $100 \%$ atau seluruhnya guru yang mengajar penjasorkes pada SMP 6 Kota Banda Aceh menyatakan paham tujuan pembinaan usia dini.

Tabel Adakah Bapak/Ibu merencanakan pembinaan usia dini

\begin{tabular}{|c|c|c|}
\hline Alternative Jawaban & Frekuensi & Persentase \\
\hline a. Paham & 2 & $100 \%$ \\
\hline b. Tidak paham & - & - \\
\hline c. Kurang paham & - & - \\
\hline Jumlah & 2 & $100 \%$ \\
\hline
\end{tabular}

Dari tabel diatas menunjukkan bahwa 2 orang guru atau $100 \%$ menyatakan merencanakan pembinaan usia dini. Dengan demikian dapat disimpulkan bahwa, $100 \%$ atau seluruhnya guru yang mengajar penjasorkes pada SMP 6 Kota Banda Aceh menyatakan paham tentang merencanakan pembinaan usia dini.

Tabel Apakah pembinaan usia dini yang ada disekolah ini telah memadai

\begin{tabular}{|l|c|c|}
\hline \multicolumn{1}{|c|}{ Alternative Jawaban } & Frekuensi & Persentase \\
\hline a. Memadai & - & - \\
b. Tidak memadai & - & - \\
c. Kurang memadai & 2 & $100 \%$ \\
\hline \multicolumn{1}{|c|}{ Jumlah } & 2 & $100 \%$ \\
\hline
\end{tabular}

Dari tabel diatas menunjukkan bahwa 2 orang guru atau $100 \%$ menyatakan pembinaan usia dini yang ada disekolah tersebut kurang memadai.

Dari pernyataan diatas dapat disimpulkan bahwa, 100\% atau semua guru penjasorkes SMP 6 Kota Banda Aceh menyatakan pembinaan usia dini yang ada disekolah ini kurang memadai.

Tabel Jika Bapak/Ibu menjawab pertanyaan diatas "tidak memadai", Bagaimana Bapak/Ibu melaksanakan pembinaan usia dini?

\begin{tabular}{|c|c|c|}
\hline Alternative Jawaban & Frekuensi & Persentase \\
\hline a. $\quad$ Membiarkan saja & - & - \\
\hline $\begin{array}{l}\text { b. Mengembangkan potensi anak usia } \\
\text { dini yang ada }\end{array}$ & 2 & $100 \%$ \\
\hline $\begin{array}{l}\text { c. Mendatangkan pelatih yang } \\
\text { berkualitas }\end{array}$ & - & - \\
\hline Jumlah & 2 & $100 \%$ \\
\hline
\end{tabular}

Dari tabel diatas menunjukkan bahwa 2 orang guru atau $100 \%$ menyatakan mengembangkan potensi anak usia dini yang ada

Dari pernyataan diatas dapat disimpulkan bahwa, 100\% atau pada umumnya guru penjasorkes pada SMP 6 Kota Banda Aceh mengembangkan potensi anak usia dini yang ada.

Tabel Bagaimana keberadaan pembinaan usia dini di sekolah Bapak/Ibu.

\begin{tabular}{|c|c|c|}
\hline Alternative Jawaban & Frekuensi & Persentase \\
\hline a. Baik & - & - \\
b. Cukup baik & - & - \\
c. kurang baik & 2 & $100 \%$ \\
\hline Jumlah & 2 & $100 \%$ \\
\hline
\end{tabular}

Dari tabel diatas menunjukkan bahwa 2 orang guru atau $100 \%$ menyatakan keberadaan pembinaan usia dini di sekolah kurang baik. 
Dari pernyataan diatas dapat disimpulkan bahwa, 100\% atau semua guru penjasorkes menyatakan keberadaan pembinaan usia dini pada SMP 6 Kota Banda Aceh kurang baik.

Tabel Bagaimana upaya Bapak/Ibu memenuhi pembinaan usia dini di sekolah?

\begin{tabular}{|c|c|c|}
\hline Alternative Jawaban & Frekuensi & Persentase \\
\hline a. Berusaha melengkapinya & 2 & $100 \%$ \\
\hline $\begin{array}{l}\text { b. Menunggu pihak lain yang } \\
\text { membantu } \\
\text { c. Melibatkan orang tua siswa }\end{array}$ & - & $\begin{array}{l}- \\
-\end{array}$ \\
\hline Jumlah & 2 & $100 \%$ \\
\hline
\end{tabular}

Dari tabel diatas menunjukkan bahwa 2 orang guru atau $100 \%$ menyatakan berusaha melengkapinya yang sudah ada disekolah. Dapat disimpulkan bahwa, 100\% atau seluruhnya pada SMP 6 Kota Banda Aceh berusaha melengkapinya yang sudah ada disekolah.

Tabel Menurut Bapak/Ibu, Adakah dukungan pihak lain dalam pembinaan usia dini

\begin{tabular}{|c|c|c|}
\hline Alternative Jawaban & Frekuensi & Persentase \\
\hline a. Ada & - & - \\
\hline b. Tidak ada & - & - \\
\hline c. Kadang-kadang & 2 & $100 \%$ \\
\hline Jumlah & 2 & $100 \%$ \\
\hline
\end{tabular}

Dari tabel diatas menunjukkan bahwa 10 orang guru atau $100 \%$ menyatakan kadang-kadang ada dukungan pihak lain dalam dalam pembinaan usia dini disekolah.

Dari pernyataan diatas dapat disimpulkan bahwa, 100\% atau semua guru penjasorkes pada SMP 6 Kota Banda Aceh menyatakan terkadang ada pihak lain yang membantu dalam dalam pembinaan usia dini disekolah.

Tabel Jika Bapak/Ibu menjawab pertanyaan diatas "ada", pihak mana saja yang terlibat

\begin{tabular}{|c|c|c|}
\hline Alternative Jawaban & Frekuensi & Persentase \\
\hline a. Sekolah & - & - \\
\hline b. Orang tua & 2 & $100 \%$ \\
\hline c. Dinas terkait & - & - \\
\hline d. Donator lainnya & - & - \\
\hline Jumlah & 2 & $100 \%$ \\
\hline
\end{tabular}

Dari tabel diatas menunjukkan bahwa 2 orang guru atau $100 \%$ menyatakan orang tua yang turut mendukung dalam yang terlibat disekolah.

Dari pernyataan diatas dapat disimpulkan bahwa, 100\% atau semua guru penjasorkes pada SMP 6 Kota Banda Aceh menyatakan orang tua yang terlibat disekolah.

Tabel Apakah Bapak/Ibu mengalami kendala dalam pembinaan usia dini disekolah

\begin{tabular}{|c|c|c|}
\hline Alternative Jawaban & Frekuensi & Persentase \\
\hline a. Ada & 2 & $100 \%$ \\
\hline b. Tidak ada & - & - \\
\hline c. Kadang-kadang & - & - \\
\hline Jumlah & 2 & $100 \%$ \\
\hline
\end{tabular}

Dari tabel diatas menunjukkan bahwa 2 orang guru atau $100 \%$ menyatakan mempunyai kendala. Dari pernyataan diatas dapat diambil kesimpulan bahwa, 100\% atau semua guru penjasorkes pada SMP 6 Kota Banda Aceh mempunyai kendala dalam pembinaan usia dini disekolah 
Tabel Jika Bapak/Ibu menjawab pertanyaan diatas “ada". Kendala apa yang Bapak/Ibu alami?

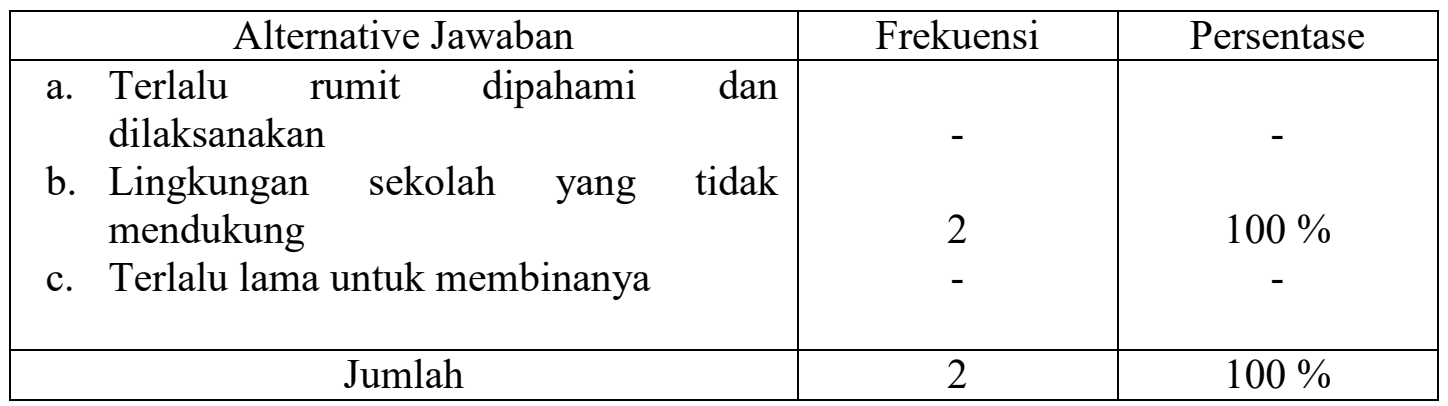

Dari tabel diatas menunjukkan bahwa 2 orang guru atau 100\% menyatakan terkendala dengan lingkungan sekolah yang tidak mendukung.

Dari pernyataan diatas dapat disimpulkan bahwa, 100\% atau semua guru penjasorkes pada SMP 6 Kota Banda Aceh menyatakan terkendala dengan lingkungan sekolah yang tidak mendukung.

\section{Tinjauan Terhadap Pertanyaan Penelitian}

Partisipasi guru penjas dalam membina prestasi usia dini di Team Gala Siswa ditinjau dari 3 komponen, adapun pertanyaan penelitian yang peneliti ajukan sebagai berikut:

\section{Bagaiman partisipasi guru penjas dalam membina prestasi usia dini di Team Gala Siswa pada SMP 6 Kota Banda Aceh?}

Untuk memberi jawaban terhadap pertanyaan diatas, maka peneliti mengacu kepada pertanyaan angket nomor 4, 5, 6, 7, 8, 9, dari jawaban tabel diatas dapat disimpulkan bahwa, $100 \%$ atau dapat dikategorikan pada umumnya berupaya Partisipasi guru penjas dalam membina prestasi usia dini.

\section{Bagaimana keberadaan dalam membina prestasi usia dini pada SMP 6 Kota \\ Banda Aceh?}

Untuk memberikan jawaban tentang pertanyaan diatas maka peneliti mengacu pada pertanyaan angket nomor $10 \mathrm{di}$ atas. Dapat disimpulkan bahwa, 100\% atau semua guru penjasorkes menyatakan partisipasi guru penjas dalam membina prestasi usia dini pada SMP 6 Kota Banda Aceh kurang baik ini juga terlihat dari hasil observasi peneliti tentang keberadaan membina usia dini disekolah tersebut. Keseluruhan guru penjasorkes menjaga serta berusaha melengkapi progeam latihan disekolah dan meminta dukungan dari pihak (donator) lain demi kelengkapan tersebut.

\section{Apa yang menjadi kendala guru pendidikan jasmani dalam membina prestasi usia dini pada SMP 6 Kota Banda Aceh?}

Untuk memberikan jawaban tentang pertanyaan diatas peneliti mengacu pada angket nomor 11, 12, 13, 14 dan 15 diatas, dapat disimpulkan bahwa, 100\% atau semua guru penjasorkes pada SMP 6 Kota Banda Aceh mempunyai kendala dalam membina prestasi usia dini, $100 \%$ atau semua menyatakan terkendala dengan lingkungan sekolah yang tidak mendukung.

\section{Pembahasan Hasil Penelitian}

Dari hasil penelitian dapat disimpulkan bahwa, secara umum guru penjasorkes pada SMP 6 Kota Banda Aceh telah berupaya membina usia dini. Hal ini dapat dibuktikan bahwa 100\% guru menyatakan membina usia dini dengan memodifikasi program latihan yang ada. 
Keberadaan membina usia dini pada SMP 6 Kota Banda Aceh masih sangat kurang baik, hal ini dapat dibuktikan bahwa 100\% atau semua guru menyatakan keberadan disekolah kurang baik. Berhasil dan tidaknya membina usia dini ditentukan oleh beberapa faktor salah satunya adalah sarana dan prasarana olahraga sebagai alat untuk menjalankan kegiatan membina usia dini. Walaupun mengalami kekurangan dalam pengadaan sarana dan prasarana olahraganya namun hal ini bukan merupakan hambatan bagi sekolah dalam menyelenggarakan membina usia dini. Dalam hal ini guru dituntut lebih kreatif dalam memberdayakan sarana dan prasarana serta siswa yang dimiliki sekolah.

\section{Kesimpulan}

Berdasarkan hasil penelitian yang telah dilakukan tentang partisipasi guru penjas dalam membina prestasi usia dini di Tim Gala Siswa SMP 6 kota Banda Aceh tahun 2020, dapat diambil kesimpulan sebagai berikut:yaitu Banda Aceh pada umumnya telah berupaya partisipasi dalam membina prestasi usia dini di Tim Gala Siswa. Guru penjasorkes pada SMP 6 kota Banda Aceh terkendala dengan lingkungan sekolah yang kurang mendukung dalam membina prestasi usia dini di Tim Gala Siswa

\section{DAFTAR PUSTAKA}

Undang-undang No. 14 Tahun 2005 Tentang Guru dan Dosen

Undang-Undang Nomor 23 Tahun 2005 tentang Pendidikan Nasional

Anwar, Q. dan Syaiful S. 2004. Profesi Jabatan Kependidikan dan Guru sebagai Upaya menjamin Kualitas Pembelajaran. Jakarta: PT. Rineka Cipta

Amir, Nyak, 2006. Pembelajaran Pendidikan Jasmani. Banda Aceh: Syiah Kuala University Press

Amir, Nyak dkk, 2005. Pembelajaran Pendidikan Jasmani. Disekolah Dasar Praktik Dan Dedaktik. Banda Aceh: Syiah Kuala University Press

Arikunto, Suharsimi, 1991. Prosedur Penelelitian Suatu Pendekatan Praktik. Jakarta: Rineka Cipta

Arsyad, Azhar, 1996. Media Pembelajaran. Jakarta: Raja Grafindo Persada

Depdiknas. 2003. Undang-Undang Republik Indonesia Nomor 20 Tahun 2003 Tentang Sistem Pendidikan Nasional

Depdiknas. 2004. Kurikulum 2004 Standar Kompetensi Mata Pelajaran Penjas Sekolah Menengah Atas , Jakarta: Balitbang

Fagas. 2006. Pendidikan usia Dini yang Baik, Landasan Keberhasilan Pendidikan Masa Depan. Darul ma'arif: Bandung.

Nurdin, Syafruddin, 2005. Guru Profesional Dan Implementasi Kurikulum. Jakarta: Ciputat Press

Muliono. 1988. Kamus Besar Bahasa Indonesia, Jakarta: Raja Grafindo Persada

Suryobroto, 2001. Pendidikan Jasmani Olahraga dan Kesehatan, Bandung: Remaja Rosda Karya

Soepartono, 2000. Sarana Dan Prasarana Olahraga. Jakarta: Departemen Pendidikan Jasmani

Tim Dedaktik Metodik, 1989. Pengantar Didaktik Metodik Kurikulum PBM. Jakarta: Rajawali 